\title{
Miért érdemes a víznevekkel foglalkozni?
}

\author{
A víznévkutatás aktuális feladatairól*
}

\author{
GYŐRFFY ERZSÉBET
}

1. E jeles alkalomra készülve KISS LAJOS alakjának felidézésekor számomra egyértelműen a víznévkutató KISS LAJOS jelent meg. Noha munkássága távolról sem merült ki a víznevek vizsgálatában, ez a terület feltétlenül meghatározó helyet foglal el életmüvében. Jól mutatja ezt az a körülmény is, hogy az 1999. január 1-jén az MTA levelező tagjaként tartott székfoglalójának az új európai víznévkutatás állt a középpontjában.

Emellett számomra KISS LAJOS kapcsán azért is a vizekkel kapcsolatos írásai idéződnek fel elsőként, mert a doktori disszertációmat 2009-ben a korai ómagyar kori folyóvíznevek témakörében védtem meg. E munkában KISS LAJOS majd két tucat írására több mint háromszáz alkalommal hivatkoztam.

Ezt a szálat mintegy újra felvéve előadásomban a víznevek fontosságára, illetve a víznévkutatás olyan kérdéseire kívánom ráirányítani a figyelmet, melyeket vagy a mai napig sem sikerült megnyugtatóan megválaszolni, vagy pedig az ezidáig elért kutatási eredmények bizonyos mértékü újragondolást, kiegészítést igényelnek.

2. A víz kiemelkedően fontos lételem Földünkön: $361125400 \mathrm{~km}^{2}$-nyi területet, azaz a Föld 70,8\%-át víz borítja. A víz az ember, emellett természetes és épített környezete számára is elengedhetetlen. A régiségben a letelepedés igen gyakran a nagyobb folyók völgyeiben történt, ezzel biztosítva az élethez a megfelelö körülményeket

Ez azonban önmagában még aligha lenne elegendő ahhoz, hogy a vizek és a neveik a nyelvészek, névkutatók, történészek stb. érdeklődését is felkeltsék. E régóta megnyilvánuló érdeklődés megítélésem szerint részben a hidronimáknak a helynevek csoportján belül betöltött sajátos szerepével függ össze. Az első fontos kérdés ezért, amire választ kell keresnünk, az, hogy mivel magyarázhatjuk a vízneveknek ezt a különleges jelentőségét.

* A 2018. június 1-jén, a Kiss Lajos-díj átadó ünnepségén, Debrecenben elhangzott előadás szerkesztett változata. 
A víznevek a helynevek legarchaikusabb rétegéhez tartoznak. A legnagyobb folyók nevei (Duna, Tisza, Szamos, Maros, nem magyar nyelvterületről való példákat is említve: Loire, Szajna, Volga stb.) századok, sőt évezredek óta léteznek, s életüket nyomon követve azt is láthatjuk, hogy nem nagyon változnak. KISS LAJOS ezt az állandóságot a nevek ,nemzetköziségével” magyarázza, azzal tudniillik, hogy a nagy folyók nevei valójában nemzetközi tulajdonban vannak (2000: 1). Ezt úgy kell értenünk, hogy a folyók partján folyamatosan éltek egyidejűleg és egymást váltva is különböző népek, amelyek nyelvében továbbhagyományozódtak, és hosszú ideig fennmaradtak ezek nevei is.

Emellett a víznevek és a más névfajták közötti szoros kapcsolat miatt is kitüntetett figyelmet érdemelnek a hidronimák. Empirikus vizsgálatok nélkül, pusztán intuícióinkra hagyatkozva is bátran kijelenthetjük, hogy víznévből alakult elnevezéssel mindenféle helynévfajta elemei között találkozunk. Mikro- és makrotoponimák létrehozásában egyaránt szerepet játszottak a víznevek, lásd pl. Bodrogköz tájnév, Sárospatak településnév, Aszalósér hegynév, Almás-völgy völgynév < Almás pataknév, Békás-szoros szoros elnevezése < Békás pataknév, Csörgölyuk barlang neve < Csörgö-patak pataknév (bővebben lásd GYŐRFFY 2011: 153171).

3. Mindennek fényében nem meglepő, hogy a kutatók figyelmét régóta felkeltették a víznevek: azok gyüjtésével, rendszerezésével, elemzésével jó néhányan foglalkoztak már a modern tudományosság kezdetétől, a 19. század végétől kezdődően is a magyar névkutatásban. Megemlíthetjük közülük ORTVAY TIVADAR 1882-ben megjelent Magyarország régi vízrajza a XIII-ik század végeig címü kétkötetes munkáját, mely mintegy 3050 folyó- és 1050 állóvíz nevét, adatait tartalmazza. ZOLTAI LAJOS a Debrecen vizei (1935) címü tanulmányában Debrecen hajdani vízrajzának összeállítását tüzte célul. PAIS LÁSZLÓ a Zala vízgyüjtöjének a vízszabályozások előtti képét rekonstruálta a történeti forrásokban található víznevek segítségével (1942).

A 20. század első felében az adattárak közreadása mellett az etimológiai és tipológiai természetủ vizsgálatok felerősödését tapasztalhatjuk. Az elsősorban területi alapon szerveződő írások jobbára a trianoni békediktátummal elszakított területek víznévi anyagát állítják a középpontba: KNIEZSA ISTVÁN Erdély és a vele összefüggő nyugati területek folyóinak és nagyobb patakjainak elnevezéseit mutatta be (1942), BENKÖ LORÁND Erdély legsürübben lakott területének, a Nyárád folyó völgyének a település-, víz- és határneveit dolgozta fel (1947). KNIEZSA ISTVÁN és BENKÖ LORÁND emellett cikksorozatban vitatta meg Székelyföld vízneveinek kérdését általánosabb, névrendszertani kérdéseket is érintve (KNIEZSA 1948a, 1948b, BENKÖ 1948). E disputa során mondták ki tudós elődeink határozottan azt az igényt, hogy egy név eredetének feltérképezéséhez feltétlenül hozzátartozik annak feltárása is, hogy egy jövevénynév milyen nyelvben nyerte el 
tulajdonnévi státusát, illetve az átadó nyelvben milyen névadási motivációt kapcsolhatunk hozzá (BENKÖ 1948).

Munkássága során ezt az elvet szem előtt tartva KISS LAJOS jelentős számú víznév etimológiáját adta közre. A Földrajzi nevek etimológiai szótára magyar nyelvü vagy magyarországi helynévi adatai között minden huszadik elnevezés víznév, e korpusznak pedig majd a kétharmada jövevénynév. A föként az 1990es években született írásaiban újfajta nézőpont bevezetésére is törekedett KISS LAJOS: a nevek származási rétegei mellett a kronológiai rétegződésüket is igyekezett feltárni.

A magyar víznévrendszer kronológiai és származásbeli rétegei között elkülönítette az ókorból adatolható, ősi indoeurópai vízneveket (pl. Garam, Kiszuca, Morva), a középkorból dokumentált víznevek csoportján belül pedig részletes tárgyalást kaptak általa a preszláv (pl. Árva, Bódva, Hernád, Nyitra, Tarca, Vág), a szláv (pl. Bebre, Kompa, Litva, Miava, Ocsova, Rima, Szalatna, Zsitva), a magyar (pl. Balog, Bodrog, Búr-patak, Horhod, Sajó, Szekcsö, Ung), valamint a német eredetủ vagy közvetítésủ víznevek (pl. Gölnic, Korpona, Selmec). Készültek dolgozatai továbbá a középkorból adatolható ismeretlen vagy bizonytalan eredetü nevekröl is (pl. Ipoly, Laborc, Latorca). (Lásd ehhez a témakörhöz bővebben pl. KISS 1994, 1996, 1997a, 1997b.)

E rétegek kapcsán jó néhány kérdés azonban még ma is megválaszolásra vár. Ezekről ejtek szót a következőkben.

4. Elsőként az ókorból adatolható, óeurópai eredetủ víznevekről célszerü szólnunk. E névcsoport eredetének meghatározása több mint egy évszázada foglalkoztatja a nemzetközi víznévkutatást, s kezdetben igencsak nagy bizonytalanság jellemezte az ezek megfejtésére irányuló kísérleteket. Póczos RITA két évvel ezelött, a mostanihoz hasonló alkalomból tartott előadásában így foglalta össze e bizonytalanság okait: ,a kutatók már a tudományos vizsgálatok kezdetekor megállapították: ezek a nevek nem köthetök egyetlen ma ismert nyelvhez sem, felismerték a nevekben a rekonstruált indoeurópai alapszavakat, ugyanakkor azt a kronológiai (és nyelvi) hézagot nem tudták kitölteni, amelyet az egykori indoeurópai alapnyelv és a későbbi önálló nyelvek között tapasztaltak. Így vezethettek a próbálkozások két olyan nyelvhez (nyelvcsaládhoz), amelyeknek a létezéséről ugyan minimális, de mégis használható információval rendelkeztek: ókori feljegyzésekből mind a kelta, mind az illír nyelv(csoport) korára, földrajzi elhelyezkedésére lehetett következtetni (bár az etimológiai kísérletekben látjuk, hogy ez utóbbit az elképzeléseiknek megfelelően jócskán kiterjesztették a kutatók). Az azonban, hogy ezeknek a nyelveknek a tényleges nyelvi alkatáról meglehetősen kevés tudásunk van, egyáltalán nem szabott gátat a névkutatók fantáziájának.” (2016: 84-85).

A múlt század közepe óta ROZWADOWSKI (1948) és KRAHE (1964) nyomán e neveket az ún. óeurópai víznévrendszerhez szokás sorolni. Az óeurópai jelző 
KRAHE értelmezésében azt a nyelvtörténeti korszakot jelöli, amely az indoeurópai ősnyelv és az egyes nyelvek kialakulása közötti fejlődési szakaszt foglalja magában. Tanítványa, WOLFGANG P. SCHMID azonban már csupán a víznévkincs egy speciális nyelvi-kronológiai rétegeként definiálja a terminust: ide tartoznak az indoeurópai nyelv alapelemeiből felépülö, i. e. 1500-tól keletkező, a mai Európa területén lévő víznevek (1981). KISS LAJOS korábban említett akadémiai székfoglalójában ekképpen foglalja össze az ún. óeurópai hidronimák jellemzőit: „1. Ne legyen megmagyarázható abból a nyelvből vagy annak elözményeiből, amelyet az általa jelölt víz mentén beszélnek vagy beszéltek. 2. Indoeurópai etimonnal és az ősi indoeurópai örökségre jellemző morfológiai szerkezettel kell rendelkeznie. 3. Jelentésének a »víz, folyó, folyás, folyadék« szómezőhöz kell tartoznia, illetőleg a víz valamely tulajdonságára kell utalnia. 4. Európai, s nem Európán kívüli folyó- vagy állóvizet kell jelölnie. 5. Tövét és szerkezetét tekintve Európában még legalább egy ősi víznév tartozzék a rokonságába mint etimológiai megfelelés." (2000: 7).

Az elméletet utóbb SCHMID tovább finomította, s hat kritériumból álló rendszert dolgozott ki az óeurópai víznévrendszerbe való soroláshoz (1973, lásd ehhez Póczos 2016: 89-90).

E kronológiai és származásbeli réteg említése kapcsán nem mehetünk el szó nélkül amellett, hogy míg a nemzetközi szakirodalomban élénk vita is kerekedett a teória helyességéről, elfogadhatóságról, és számos monográfia is készült a témakörben, addig a magyar víznevekkel foglalkozó szakirodalom alig fordított figyelmet az etimológiai vizsgálatokban az efféle eredeztetés lehetőségére. Ebben a tekintetben KISS LAJOS munkássága hozott új színt, ő ugyanis számos írásában és a FNESz. szócikkeiben számol ezzel a réteggel, noha nem óeurópai eredetüként utal rájuk. Az utóbbi évtizedben ez a megközelítés, elsősorban Póczos RITA több munkája révén, erőteljesebben is megjelenni látszik a hazai névkutatásban.

PÓCzos RiTA ugyanakkor tovább is lépett a kérdésben elödeinél. Rámutatott arra, hogy nem csupán a nagyobb folyók elnevezései között találhatunk óeurópai ősiségü neveket, hanem kisebb patakok nevei is fennmaradhattak akár több évezreden keresztül, ennek egyetlen feltétele ugyanis az egymással érintkező folyamatos lakosság (Póczos 2004: 121, lásd ehhez KISS 2000: 7 is). Póczos RITA pusztán a víznév hangalakszerkezete alapján — a magyar vagy más átadó nyelvủ (szláv, germán) eredeztetés lehetősége mellett — az óeurópai származtatás lehetőségét sem veti el az Apoka pataka (<*āp- 'víz, folyó'), Balog (*bholghāa'duzzad, dagad'), Lubna (<*leu, *leuə-, *lü- 'kosz, bepiszkol' tő - $b$-vel bővült variánsa), Szartos (<*ser, *sor- 'folyik, áramlik') (e nevekhez lásd 2003: 491); Libercse (<*leib-, loib-, lib- 'öntöz, folyik, nedves'), Litva <*leu, *leuə-, *lü'piszkol, bepiszkol'), Poltár (< pol-, pel-, pl- 'önt, folyik') (e nevekhez lásd 2004: 
122-123) nevek esetében. Újabb írásaiban a pusztán egyetlen adattal rendelkező Lupa név kapcsán is felveti, hogy (más lehetséges magyarázatok mellett) esetleg óeurópai ôsiségü is lehet a név (<*leup-, leub-, leubh- 'lehánt, meghámoz, letör, megrongál', PócZOS 2015).

Az említett nevek esetében a többféle nyelvből való eredeztetés azzal magyarázható, hogy a valójában óeurópai gyökerü név az átvevő nép nyelvének egy szemantikailag is megfelelő szavával mutat hasonlóságot, s így az új névhasználó közösség ennek a szónak a tartalmát érthette bele a víznévbe, s ahhoz igazíthatta a jövevénynév hangalakját.

E rövid összefoglaló végén fontos hangsúlyoznunk, hogy noha a teória követői maguk is utalnak az óeurópai elmélettel kapcsolatos bizonytalanságokra, megválaszolandó kérdésekre, a víznév-etimológiai kutatásokban azonban mindenképpen számolnunk kell ezzel a névréteggel is. Ez különösen annak fényében tartandó szem elött, hogy a Kárpát-medence folyóvíznevei között több tucatnyi olyan név található, amelynek eredetére a víznévkutatók mindezidáig nem tudtak megnyugtató magyarázatot adni.

Az ún. óeurópai nevek eredetének vizsgálata mellett természetesen más kérdések is felmerültek e névréteg kapcsán a kutatókban. Közülük kiemelendő többek között az, hogy a népességtörténeti kutatásokban mennyiben használhatók fel, azaz milyen forrásértékük van az efféle elnevezéseknek. Emellett az sem lényegtelen tudományos szempontból, hogy a korai oklevelek megszövegezői milyen nyelven rögzítették őket a dokumentumokban. Ezeket a kérdéseket azonban itt most nem érintem.

5. Az, hogy KISS LAJOS élénk érdeklődést mutatott a víznevek iránt, minden bizonnyal összefüggött azzal a körülménnyel is, hogy alapképzettségét tekintve szlavista volt. Márpedig legősibb vízneveink szláv közvetítéssel kerültek be a nyelvünkbe, nemegyszer magukon viselve a szláv nyelv alakító hatását is. Emellett az ómagyar korban átvett neveink nagy része szintén valamely szláv nyelvből került át a magyar helynévkincsbe. E névréteg vizsgálatát értelemszerüen olyan kutatók tudták és tudják ma is a legmegbízhatóbb módon elvégezni, akik a szlavisztika területén is otthonosan mozognak. KISS LAJOS elődei közül e tekintetben elsősorban MELICH JÁNOS és KNIEZSA ISTVÁN nevét említhetjük meg.

A valamely szláv nyelvből átvett víznevek legkorábbi rétege a korai ómagyar korból adatolható. E korszak negyven vármegyéjének víznévi anyagát feldolgozó elemzéseim azt mutatják, hogy a más nyelvekböl kölcsönzött hidronimák között a szláv jövevénynevek vannak jelen a legnagyobb számban: az összes jövevénynév több mint háromnegyede tartozik közéjük (vö. GYÖRFFY 2011: 136).

Jó néhány olyan kérdés merülhet fel e témakör kapcsán, melyekre szlavista kollégáinktól remélhetünk válaszokat. Ezek elsősorban a kronológiával kapcsolatosak, mégpedig rögtön két problémát is érintve: egyrészt mikor keletkeztek e 
szláv eredetü víznevek, másrészt mikor kerülhettek át a magyar helynévrendszerbe. Ezek a kérdések persze több szempontból is nehezen megválaszolhatók. A nevek ugyanis már az oklevelekbe kerülésük elött is léteztek, s a létrejöttük idejének a meghatározása e legrégebbi névréteg esetében minden bizonnyal feltárhatatlan. A később keletkezett neveket is nyilvánvalóan jellemzi egyfajta esetlegesség az adatolás szempontjából, ennek eredményeképpen pedig a víznevek között — csakúgy, mint más névfajták, például a településnevek esetében — csupán egyfajta relatív (azaz egymáshoz viszonyított) kronológiát állapíthatunk meg.

Az átvétel idejének meghatározása pedig akkor végezhető el nagyobb valószínüséggel, ha az átadó vagy átvevő nyelvben valamilyen hangtörténeti változás a segítségünkre van ebben. Ez a vizsgálati szempont azért különösen lényeges, mert ezáltal esetleg elkülöníthetők lehetnének a letelepedés előtti szláv eredetü víznevek és a magyarsággal együtt élő szláv lakosság által később adott elnevezések. Ehhez a szláv helynévi anyag szisztematikus összegyüjtésére és alapos feldolgozására van szükség, mely nemcsak a magyar és a szláv víznévkutatás számára hozhat gyümölcsöző eredményeket, hanem a Kárpát-medencében egykor beszélt szláv nyelvvel vagy nyelvekkel kapcsolatos ismereteket is bővítheti. (A problémakörről bővebben lásd HOFFMANN-RÁCZ-TÓTH 2017: 90-95, 2018: 388-395.)

6. A kérdést még csak röviden sem vázolva jelzem továbbá azt, hogy ugyanez vonatkozik a törökségi népektől kölcsönzött víznevekre is, melyekről még kevesebb és csak igen homályos, ellentmondásos ismerettel rendelkezünk. (Lásd ehhez például MAKKAI etimológiai fejtegetéseit: 1987: 250 vagy LIGETI 1986.) Ez ügyben HOFFMANN ISTVÁN kritikai állásfoglalásával érthetünk egyet, hogy tudniillik „komoly hiányosságok is megmutatkoznak az etimologizálásban: a törökségi nyelvekből magyarázott régebbi helynevek megfejtésében például a turkológia belső névrendszertani bizonyítékokat, analóg névkeletkezési módokat aligalig szokott előhozni” (2007: 16, vö. még HoFFMANN-RÁCZ-TóTH 2018: 140). Itt a kutatásokat megnehezíti egyrészt az ide tartozó nevek kis száma (pl. Karas, Krassó, esetleg Küküllö stb.), de azt sem könnyü megítélni, hogy e nevek melyik törökségi nyelvvel hozhatók kapcsolatba. Sajnálatos, hogy a mai turkológusok közül — tudomásom szerint — senki nem foglalkozik szisztematikusan a Kárpátmedence törökségi nyelvekből való helyneveivel és így a vízneveivel sem.

7. Érdemes lehet a különböző nyelvek víznévrendszereit is összevetni egymással, mégpedig két különböző szempontot szem elött tartva. Egyrészt a magyarral rokon nyelvek (például a finn) elnevezéseit célszerű bevonnunk az efféle vizsgálatokba, másrészt nem rokon, de a magyarral érintkező nyelvek (például a szláv) víznévállományát is összehasonlíthatjuk a magyar nevekkel. A funkcionális nyelvszemlélet kiváló keretet biztosíthat az összehasonlításhoz, hiszen itt a névrendszert jellemző sémák kerülnek az elemzés fókuszába: az empirikus adatokból kiindulva, induktív módon jutunk el az általánosításokhoz, jelen esetben a 
névmodellekhez. A nem rokon nyelvekkel való összevetés azért is hozhat különösen érdekes eredményeket, mert így felszínre kerülhetnek a területi-kulturális kapcsolatokból, illetve nyelvi szempontból a kétnyelvüségből fakadó hatások, melyek lenyomatát az érintkező nyelvek névrendszerei is magukon viselhetik.

Az összehasonlító vizsgálatok lehetőségeit én magam régi svéd és magyar víznevek közötti hasonlóságokat és különbségeket elemző írásomban próbáltam bemutatni (GYÖRFFY 2008). A minél szélesebb körü analízishez azonban jó példát szolgáltathat a TÓTH VALÉRIA által szerkesztett Patrociny Settlement Names in Europe címü kötet, mely az olasz, spanyol, francia, német, lengyel és Kárpátmedencei patrocímiumi eredetü településnevek jellegzetességeit járja körül (2011). Úgy látom, hogy a különböző nyelvű víznévrendszerek összevetésére irányuló program is nemzetközi kutatógárda bevonásával valósulhat meg a legeredményesebben. Ennek ösztönzését személyes feladatomnak is tekintem.

8.1. A magyar nyelvterületről adatolható víznevek vizsgálatában a múltban az etimológiai jellegủ kutatások voltak a meghatározók, és ezek is főképpen a nem magyar eredetü nevekre összpontosították a figyelmet, illetve azokra, amelyek etimológiai tekintetben nem transzparensek. Én magam úgy gondoltam, hogy a régi magyar víznévadás rendszerszerü vizsgálatát is célszerü elvégezni, ezért tanulmányok sorát, majd doktori értekezést és ebből kinőtt monográfiát szenteltem a témának. Ebben a névrendszert szemantikai, lexikális-morfológiai, valamint keletkezéstörténeti szempontból jellemeztem (lásd GYÖRFFY 2011).

Az általam elkészített korai ómagyar kori folyóvíznevekre irányuló tipológiai jellegủ munkából megtudhatjuk, hogy a korai ómagyar folyóvíznevek szerkezeti szempontból vizsgálva igen sokszínü képet mutatnak. Az egy- és kétrészes víznevek megoszlása közel azonos: $51: 49 \%$. Az egy- és kétrészes nevek kronológiai megoszlását nyomon követve ugyanakkor azt is tapasztalhatjuk, hogy a legrégebbi víznevek egyrészesek voltak, majd az idő előrehaladtával a kétrészes nevek váltak jóval gyakoribbá.

A hely fajtáját megjelölő egyrészes nevek (mint például az Ér vagy a Séd) ritkán ugyan (4\%), de előfordulnak a régi nevek között. A víznévben megjelenő nyelvi elemek gyakrabban utalnak arra, hogy a névvel megjelölt víznek milyen jellegzetességei vannak (23\%). A fajtajelölő és a sajátosságfunkció egymással kombinálódva is megjelenik a nevek több mint egynegyedében (27\%).

A sajátosságot kifejező névrészfunkciókat a bennük kifejezett szemantikai tartalom alapján tovább differenciálhatjuk. A régi magyar folyóvíznevekben leggyakrabban a 'víz valamely más helyhez (elsősorban településhez) való viszonya' szemantikai tartalom fejeződik ki: Barót, Szentkirály pataka. A víz környéki növényzet szintén gyakran szolgáltatta a névadási alapot: Körös, Bükk-sevnice (ezzel szemben az állatvilág jóval kevesebb esetben jelenik meg motivációként: Compó, Férges-ér). A harmadik leggyakoribb kategóriát olyan víznevek alkotják, 
amelyek valamely a vízzel kapcsolatba hozható személyre vagy csoportra utalnak: Milos, Encs ere, Prépost pataka.

A nevek kisebb részében jelentette a névadási motivációt a víz mérete (Keskeny, Mélyes, Kis-patak), alakja (Kengyeles, Kürtös pataka), színe (Fekete-patak, Kék-Kálló), íze (Sós-patak), hőmérsékleti jellemzője (Hideg-séd, Meleg-Szamos), hanghatása (Hangony, Zúgó-fok), állapota (Aszú-Szartos, Romlott-patak), sebessége, mozgása (Lassú-ág, Sebes-Vajas), anyaga (Agyagos, Köves-patak).

Pusztán megnevező névrészt tartalmazó egyrészes név szép számmal (24\%) fordul elő a víznevek körében, az átvett jövevénynevek adják ezt a réteget: Duna, Klukucs, Tepla. A megnevező előtagú és a hely fajtáját megjelölő utótagú kétrészes neveket (14\%) az előtag jellege alapján két csoportba oszthatjuk. Egyik részükre az jellemzö, hogy az első névrész névátvétellel került nyelvünkbe, tehát idegen eredetü víznév (Szitnyice > Szitnyice pataka). A másik csoportba olyan nevek tartoznak, melyek első névrésze belső keletkezésü víznév (Aranyos > Aranyos pataka). Emellett egy már létezö, átvett vagy belső keletkezésü víznév kaphat olyan megkülönböztető szerepủ előtagot is, mely a víz valamely sajátosságára utal, ezek többnyire a megnevező névrész által jelölt víz mellékágának vagy holtágának az elnevezései: Nagy-Ilosva, Váradi-Körös, Közép-Sár.

Dióhéjban érdemes szólni a korai ómagyar kori névanyagban megjelenő keletkezéstörténeti módok arányáról is. E korszakban a szintagmatikus szerkesztéssel keletkezett folyóvíznevek adják a legnagyobb csoportot (32\%): Sebes-patak, Somogyi-Bódva.

Nem meglepő, hogy a belső névkeletkezési mód mellett a külső névalkotás is tekintélyes szerepet kapott a magyar folyóvíznévrendszer létrejöttében. Vizsgálataimból azonban kitünik, hogy nemcsak a nagyobb folyók viselhetnek idegen eredetü nevet, hanem a közép- és a kisebb vizeket is gyakran jövevénynévvel illetik: az ómagyar kori névanyag minden ötödik eleme névátvétel útján — mint láttuk korábban: leggyakrabban valamely szláv nyelvből — került a magyar nyelvbe $(21 \%)$.

A jelentésbeli névalkotás a közepesen gyakran előforduló névkeletkezési típusok között említendő (14\%). A kategórián belül a jelentéshasadással létrejött elnevezések sokkal kisebb arányban szerepelnek (Ér, Fok, Sár), mint a metonimikus víznevek (Boltárgy, Gyürü, Úz). Hasonló arányt tapasztalunk a név terjedelmét érintő szerkezeti változás útján keletkezett vízneveknél is (12,5\%): Béla $>$ Béla-patak, Gyümölcsény > Gyümölcsényes. A folyóvíznevekre a legkevésbé jellemző alakulási mód pedig a morfematikus szerkesztés ebben a korszakban (9,5\%): Köved, Gyiógy, Egres.

8.2. A korai ómagyar kori víznevek rendszertani leírása további fontos és szintén megválaszolandó kérdéseket is előhozott. Ilyen a névrendszer állandóságának és változásának problematikája. 
KISS LAJOS maga is ír munkáiban több ízben is a kontinuitás kérdéséröl, noha más hangsúlyokkal: írásaiban a régiségből fennmaradt és tovább örökített neveket helyezi a figyelem középpontjába (pl. 1995, 1997a). E kérdéskört tovább gondolva mindenképpen fontos lenne feltérképezni a víznevek mind területi, mind kronológiai állandóságát vagy éppen változékonyságát, azt tudniillik, hogy miként és mennyiben változtak meg az idők folyamán a víznevek jellegzetes szerkezeti típusai. Egy-egy kisebb területre vonatkozóan többen is próbáltak e kérdésnek utána járni. KOCÁN BÉLA például Ugocsa vármegye ómagyar és középmagyar kori folyóvízneveit vizsgálta a névszerkezet elmozdulásának szempontjából is. Itt csak egyetlen eredményére hívom fel a figyelmet. Az 1200-as évektől 1772-ig vizsgált korpuszban azt tapasztalhatjuk, hogy az egy- és kétrészes nevek aránya megfordult: a kezdeti 58\%:42\%-os megoszlás helyett a korszak végére 44\% : 56\%-os arányszám jellemezte a folyóvízneveket (2017: 67-69), azaz a kétrészes nevek kerültek túlsúlyba. Ez egybevág azzal a tendenciával, amelyet én magam is megfigyeltem másfajta mintán a fent már említett munkámban.

8.3. A víznévkutatás kiemelkedően fontos feladata, hogy mind a szinkróniában, mind a diakróniában nagyívü, szintetizáló tipológiai vizsgálatokat végezzenek el a kutatók. Ezáltal ugyanis képet kaphatunk a magyar helynévrendszer egy fontos, jól vizsgálható részrendszerének történeti változásfolyamatairól, vagyis arról, hogy a névadó ember korról korra hogyan teremtette újra változó szemléletével a környezetéröl, a környezetének e fontos részéről alkotott képet. Ez természetesen óriási vállalkozás, az olyan típusú adatbázisok segítségével azonban, mint amilyen a folyamatosan gazdagodó Magyar Nemzeti Helynévtár (http://mnh.unideb.hu/), ez a terv megvalósítható, hiszen e projekt keretében a Kárpát-medencei helynévanyag történeti és mai korpusza is felhasználóbarát módon áll a kutatók rendelkezésére.

A nagyívü, rendszerszintü tipológiai elemzések — noha nem egyediségükben ragadják meg a vízneveket — fontosak lehetnek az egyedi névrekonstrukciókban is azáltal, hogy a jellegzetes névmintákra, névmodellekre világítanak rá, amelyek a névrendszer müködését, a nevek keletkezését alapjaiban is meghatározzák. Erre láthatunk példát Póczos RITA egyik névmagyarázatában, aki a Kapos víznév kapcsán a következőket állapítja meg: „A Kapos [...] etimológiai tekintetben átlátszó szerkezetủ [ti. a kapu lexéma -s képzős származéka, Gy. E.], azonban kérdéses, hogy valóban az a motiváció húzódik-e a névadás mögött, amit a szakirodalom feltételez [ti. hogy a gyepükapuval hozható kapcsolatba a név, Gy. E.], azzal ugyanis meglehetősen magányosan állna a víznevek névadási mintái között" (PÓCZOS 2015: 80). HOFFMANN ISTVÁN a névrekonstrukció egyik alappillérének tekinti a helynév névrendszertani beágyazottságát (2007: 16, vö. még HoFFMANN-RÁCZ -TÓTH 2018: 140). E szempontból a skála egyik végpontján azok a nevek helyezkednek el, melyekre sok analógiát (azaz produktív névmodellt) 
találunk a névkincsben, míg a másik pólust azok az elnevezések képviselik, melyek társtalanul állnak a rendszerben. Az előbbiek esetében az etimológia helyessége igen valószínú, míg az utóbbiak csupán jóval kisebb bizonyossággal fogadhatók el. A nagy adatmennyiséggel dolgozó statisztikai felmérések (és az ennek révén feltárt névmodellekre vonatkozó produktivitási mutatók) tehát megerősíthetik vagy éppen gyengíthetik egy-egy névfejtés valószínüségét.

9. Összegzésként még egyszer érdemes kiemelnünk azokat a kutatási irányokat és területeket, amelyekben — megítélésem szerint — időszerü a víznévkutatásban további lépéseket tenni. A régi hidronimákkal kapcsolatos kérdések megválaszolásához mindenképpen ki kell lépni a magyar helynévkutatás szükebb berkeiből, és a modern indogermanisztika, szlavisztika és turkológia stb. eredményeit figyelembe véve, az elemzésekbe azokat beépítve kell a víznevekhez közelíteni. Ezek után a különböző nyelvekhez tartozó víznévkincs beható ismerete kiváló alapot biztosíthat a jövőbeni kontrasztív jellegü elemzésekhez is. A magyar eredetủ víznevek analízisekor pedig leginkább talán arra van szükség, hogy mind térben, mind időben kitágítsuk a tipológiai vizsgálatokat. A területi és kronológiai szempontból nagyobb névkorpuszon elvégzett vizsgálatok egyrészt finomíthatják magát a módszertant is, emellett pedig jelentősen hozzájárulhatnak az egyedi esetek körültekintőbb megítéléséhez.

\section{Irodalom}

BENKÖ LORÁND 1947. A Nyárádmente földrajzinevei. A Magyar Nyelvtudományi Társaság Kiadványai 74. Budapest.

BENKÖ LORÁND 1948. A székelyföldi szláv eredetü víznevek kérdéséhez. Magyar Nyelv 44: 95-101.

FNESz. = KISS LAJOS, Földrajzi nevek etimológiai szótára 1-2. Negyedik, bővített és javított kiadás. Budapest, Akadémiai Kiadó, 1988.

GYÖRFFY ERZSÉBET 2008. Similarities and dissimilarities between Swedish and Hungarian hydronyms. Namn och samhälle 22. Uppsala, Uppsala universitet.

GYŐRFFY ERZSÉBET 2011. Korai ómagyar kori folyóviznevek. A Magyar Névarchívum Kiadványai 20. Debrecen, Debreceni Egyetemi Kiadó.

HOFFMANN ISTVÁN 2007. Nyelvi rekonstrukció — etnikai rekonstrukció. In: HoFFMANN IsTVÁN-JuHÁSz DEZSŐ szerk., Nyelvi identitás és a nyelv dimenziói. Debrecen-Budapest, Nemzetközi Magyarságtudományi Társaság. 11-20.

HoFFmAnN, ISTVÁN-RÁCZ, ANITA-TÓTH, VALÉRIA 2017. History of Hungarian Toponyms. Hamburg, Buske.

HoFFMANN ISTVÁN-RÁCZ ANITA-TÓTH VALÉRIA 2018. Régi magyar helynévadás. A korai ómagyar kor helynevei mint a magyar nyelvtörténet forrásai. Budapest, Gondolat Kiadó.

KISS LAJOS 1994. A Felvidék víznevei. Magyar Nyelv 90: 1-19. 
KISS LAJOS 1995. Földrajzi nevek kontinuitása a Dunántúlon. Magyar Nyelv 91: 192194.

KISS LAJOS 1996. A Kárpát-medence régi helynevei. Magyar Nyelvőr 120: 440-450.

KISS LAJOS 1997a. Pannónia helyneveinek kontinuitása. In: KOVÁCS LÁSZLÓ-VESZPRÉMI

LÁSZLÓ szerk., Honfoglalás és nyelvészet. Budapest, Balassi Kiadó. 187-197.

KISS LAJOS 1997b. Erdély vízneveinek rétegződése. In: KoVÁCS LÁSZLÓ-VESZPRÉMI

LÁSZLÓ szerk., Honfoglalás és nyelvészet. Budapest, Balassi Kiadó. 199-210.

KISS LAJOS 2000. Az új európai víznévkutatás. In: GLATZ FERENC szerk., Székfoglalók a Magyar Tudományos Akadémián. 1999. Társadalomtudományok. Budapest, Magyar Tudományos Akadémia. 1-21.

KNIEZSA IsTVÁN 1942. Erdély víznevei. Kolozsvár, Minerva.

KNIEZSA ISTVÁN 1948a. Szláv eredetü víznevek a Székelyföldön. Magyar Nyelv 44: 111.

KNIEZSA ISTVÁN 1948b. A székelyföldi szláv eredetű víznevek kérdéséhez. Magyar Nyelv 44: 101-105.

KoCÁN BÉLA 2017. Helynévtörténeti vizsgálatok a régi Ugocsa megyében. A Magyar Névarchívum Kiadványai 45. Debrecen, Debreceni Egyetemi Kiadó.

KRAHE, HANS 1964. Unsere ältesten Flußnamen. Wiesbaden, Otto Harrassowitz.

LIGETI LAJOS 1986. A magyar nyelv török kapcsolatai a honfoglalás elött és az Árpádkorban. Budapest, Akadémiai Kiadó.

MAKKAI LÁSZLÓ 1987. = Erdély története. Budapest, Akadémiai Kiadó.

ORTVAY TIVADAR 1882. Magyarország régi vízrajza a XIII-ik század végeig 1-2. Budapest, Magyar Tudományos Akadémia.

PAIS LÁSZLÓ 1942. A Zala vízgyűjtőjének régi vízrajza. In: A Magyarságtudományi Intézet Évkönyve. Budapest. 68-114.

PóCzos RiTA 2003. A Sajó vízrendszerének nyelvi rétegei. Magyar Nyelvjárások 41: $105-127$.

PÓCZOS RITA 2004. A Garam és az Ipoly víznévrendszerének nyelvi rétegei. Helynévtörténeti Tanulmányok 1: 105-127.

PóCzos RiTA 2015. A Pécsi püspökség alapítólevelének szórványai: Lupa, Kapos. Helynévtörténeti Tanulmányok 11: 77-92.

PóCzOs RITA 2016. Elméletek a régi európai víznevekről. Magyar Nyelvjárások 54: 83-93.

ROZWADOWSKI, JAN 1948. Studia nad nazwami wód słowiańskich. Prace Onomastyczne

1. Kraków, Nakładem Polskiej Akademii Umiejętności.

SCHMID, WolfGANG PETER 1973. Aura und Aurajoki. Baltistica 9: 189-194.

SCHMID, WOLFGANG PETER 1981. Die alteuropaische Hydronymie. Stand und Auf-gaben ihrer Forschung. Beitränge zur Namenforschung, Neue Folge 16: 1-12.

TÓTH VALÉRIA szerk. 2011. Patrociny Settlement Names in Europe. Onomastica Uralica 8. Debrecen-Helsinki, Debreceni Egyetemi Kiadó.

Zoltai Lajos 1935. Debrecen vizei. A Debreceni Muzeumbarátok Köre kiadványai 1. Debrecen. 


\section{Why should we Study Hydronyms? On the Current Tasks of Hydronym Research}

The paper provides an overview of those research directions and areas which offer opportunities for moving forward in the research on hydronyms. In order to answer questions related to old hydronyms, we definitely need to step out of the narrower framework of Hungarian toponomastics and consider results in modern Indo-German, Slavic, and Turkish studies, among others, and integrate them into our analyses related to hydronyms. The comprehensive knowledge of the hydronym corpus of different languages may provide an excellent foundation for future comparative analyses as well. When analyzing hydronyms of Hungarian origin, we need to expand typological examinations both in space and time. Studies on a larger name corpus, both in a geographical and chronological sense, may refine the methodology itself while also contributing to a more careful perception of individual cases.

Keywords: typological and historical analysis of hydronyms, Hungarian hydronyms, actual tasks of Hungarian toponomastics 